https://jurnal.unigal.ac.id/index.php/edukasi

\title{
PEMODELAN PENCATATAN AKUNTANSI DENGAN IDENTIFIKASI AKTIVITAS UNTUK PENGANGGARAN MASJID
}

\author{
Oleh: \\ Firman Aryansyah \\ Program Studi Pendidikan Akuntansi Universitas Galuh, Indonesia \\ Email: firman_aryansyah13@yahoo.com \\ Sejarah Artikel: Diterima April 2019, Disetujui Mei 2019, Dipublikasikan Juni 2019
}

\begin{abstract}
ABSTRAK
Anggaran bagi organisasi nirlaba memiliki peran yang berbeda dibanding perannya pada perusahaan atau sektor bisnis. Pada perusahaan, anggaran ditetapkan dengan titik berat pada target penerimaan. Untuk itu produksi dan pemasaran akan dilakukan untuk mencapai target penerimaan ini. Pada organisasi nirlaba, anggaran merupakan penterjemah dari rencana kegiatan atau program organisasi dan sumber dana yang dibutuhkan. Jadi, anggaran pada organisasi nirlaba dimulai dari program atau kegiatan yang direncanakan. Kemudian diterjemahkan ke dalam satuan uang untuk selanjutnya dibandingkan dengan anggaran penerimaan. Menurut PSAK No. 45 menjelaskan bahwa komponen laporan keuangan organisasi nirlaba meliputi: (1) Laporan Posisi Keuangan, (2) Laporan Aktivitas, (3) Laporan Arus Kas. Laporan aktivitas menyajikan jumlah perubahan aktiva bersih terikat permanen, terikat temporer, dan tidak terikat dalam suatu periode. Laporan aktivitas juga menyajikan keuntungan dan kerugian yang diakui dari investasi dan aktiva lain (atau kewajiban) sebagai penambah atau pengurang aktiva bersih tidak terikat, kecuali jika penggunaannya dibatasi oleh penyumbang, dan menyajikan beban sebagai pengurang aktiva bersih tidak terikat.
\end{abstract}

Kata Kunci: Masjid, Akuntansi Entitas Nirlaba, Penganggaran

\section{PENDAHULUAN}

Al-Quran menghendaki manusia bertanggungjawab secara vertical maupun horizontal. Secara vertikal berarti mempertanggungjawabkan apa yang menjadi pelaksanaan tugasnya kepada Alloh SWT sedangkan, secara horizontal menimbulkan pertanggungjawaban yang bersifat sesama manusia.

Mesjid sebagai tempat peribadatan tidak hanya mengurusi segala hal kegiatan yang berhubungan dengan Tuhan secara langsung saja. Namun, juga mesjid sebagai refleksi tempat berkumpul serta media umat untuk menyalurkan rezekinya dalam bentuk zakat, infaq maupun sodaqoh. DKM (Dewan Kemakmuran Masjid) tentunya harus memfasilitas umat untuk melaksanakan berbagai kegiatan ibadah tersebut yang tentunya memerlukan berbagai biaya yang diperoleh dari berbagai pihak donatur. Akuntabilitas DKM dalam mengelola sumber dan pengeluaran dana umat ini jangan hanya berpedoman pada aspek akidah saja, bahwa segalanya akan dipertanggungjawabkan dihadapan Alloh SWT. namun perlu adanya keseimbangan dengan manusia juga dalam hal ini umat. Bagaimana mereka mempertanggungjawabkan keuangan umat agar tidak menimbulkan buruk sangka (suudzon). Hal ini sejalan dengan pendapat Kotler \& Keller (2009:16) bahwa "organisasi nirlaba merupakan lembaga yang dibiayai oleh masyarakat lewat sumbangan atau donasi".

Dalam menjalankan aktivitasnya masjid memerlukan dana yang harus dipertanggungjawabkan oleh Pengurus DKM kepada umat melalui berbagai cara diantaranya forum sholat jumat, laporan tertulis ke instansi (donatur) ataupun ditulis di papan pengumuman tiap-tiap masjid. 


\section{METODE PENELITIAN}

Penelitian ini merupakan jenis penelitian deskriptif eksploratif dengan pendekatan kualitatif. Penelitian bersifat deskriptif bertujuan untuk menggambarkan sifat sesuatu yang tengah berlangsung saat riset dilakukan dan memeriksa sebab-sebab dari suatu gejala tertentu (Umar, dalam Sochimin 2015: 58). Dalam penelitian ini, tidak dimaksudkan untuk menguji hipotesis tertentu hanya menggambarkan apa adanya suatu variabel, gejala, atau keadaan. Sedangkan, pendekatan penelitian kualitatif bermaksud untuk memahami fenomena apa yang dialami oleh subjek penelitian dan dengan cara deskripsi dalam bentuk narasi. Dalam penelitian ini tidak dimaksudkan untuk menguji hipotesis tertentu hanya menggambarkan apa adanya suatu variabel, gejala atau keadaan. Pada rumusan masalah digunakan pendekatan kuantitatif, dan menggunakan pendekatan kualitatif.

Variabel dalam penelitian ini adalah model pencatatan akuntansi dengan identifikasi aktivitas untuk penganggaran masjid. Instrumen yang digunakan untuk mengetahui praktik manajemen masiid dalam penganggaran keuangannya sebagaimana menurut PSAK No. 45 dapat disajikan pada tabel berikut ini.

Tabel 1:

Operasionalisasi Variabel

\begin{tabular}{cll} 
No & \multicolumn{1}{c}{ Sub Variabel } & \multicolumn{1}{c}{ Indikator } \\
\hline 1. & Identifikasi Sumber & Pendapatan terikat temporer \\
& Pendapatan & Pendapatan tidak terikat \\
\hline 2. & Identifikasi Klasifikasi & Identifikasi Nama/ Deskripsi/ Aktivitas, Tujuan, dan \\
& Aktivitas & Periode Pelaksanaan. \\
\hline 3. & Penyusunan Anggaran & Anggaran Berbasis Kinerja/ Aktivitas \\
& & Anggaran Pendapatan dan Biaya \\
& & Laporan Realiasasi Anggaran \\
& & Interpretasi Atas Laporan Anggaran dan Realisasi
\end{tabular}

Tahapan-tahapan analisis data dilakukan dengan menggunakan analisis kualitatif model Miles dan Huberman adapun tahapannya meliputi proses mengumpulkan data yang diperoleh dati observasi, wawancara, dan dokumentasi, reduksi data, penyajian data dan terakhir penarikan kesimpulan (Sugiyono, 2010:91).

Pemeriksaan keabsahan data penelitian ini menggunakan metode triangulasi. Menurut Maleong (2012:330), "teknik triangulasi adalah pemeriksaan data yang memanfaatkan sesuatu yang lain dalam membandingkan hasil wawancara terhadap objek penelitian".

\section{HASIL PENELITIAN DAN PEMBAHASAN \\ Hasil Penelitian}

Berdasarkan hasil observasi pada pengelola Masjid Baiturrohim Bojongmengger, pencatatan administrasi keuangan dibedakan menjadi dua yaitu penerimaan dan pengeluaran. Sumberdaya yang diterima setiap minggunya, kemudian dilaporkan dan dikelola oleh
Pengelola Masjid Baiturrohim untuk membiayai belanja utama yang telah ditetapkan.

1. Penerimaan Keuangan Pengelola Masjid Baioturrohim

Penerimaan Pengelola Masjid

Baiturrohim yaitu bersumber dari kotak amal, sumbangan, dan infaq. Kotak amal yang terkumpul langsung dihitung ketika selesai sholat Jum'at oleh majelis yang bertugas dan dicatat jumlahnya. Setiap penerimaan yang diterima oleh bendahara akan dicatat.

2. Pengeluaran Keuangan Pengelola Masjid Baiturrohim

Pengeluaran Pengelola Masjid Baiturrohim dibagi menjadi dua yaitu pengeluaran rutin dan pengeluaran tidak rutin. Contoh pengeluaran rutin yaitu pengeluaran rutin $\mathrm{BPH}, \mathrm{PLN}$, PDAM, personil. Sedangkan pengeluaran yang tidak rutin yaitu hari besar islam, pengislaman, konstruksi dan pemeliharaan. Setiap bagian yang berhubungan dengan aktivitas masjid yang membutuhkan dana, dapat langsung mengambilnya dari bendahara dengan syarat harus membuat bukti 
atau membuat proposal ketika akan membuat suatu kegiatan.

3. Anggaran Pendapatan dan Belanja Pengelola Masjid Baiturrohim

Aktivitas keuangan pada Pengelola Masjid Baiturrohim untuk tahun berikutnya diawali dengan membentuk anggaran pendapatan dan belanja. Anggaran pendapatan dan belanja tersebut sangat berperan penting dalam pelaporan keuangan masjid, karena semua penerimaan dan pengeluaran mengacu pada anggaran yang telah dibuat oleh pihak $\mathrm{BPH}$ (Badan Pengelola Harian). BPH Masjid Baiturrohim membuat anggaran pendapatan dan belanja untuk satu tahun kedepan.

Sebagai bahan acuan dalam pelaksanaan kegiatan masjid, penyusunan anggaran pendapatan dan belanja diusahakan sesuai dengan kebutuhan dan keperluan masjid sehingga anggaran setiap tahunnya mengalami peningkatan. Dengan adanya anggaran ini, diharapkan kegiatan yang ada di masjid dapat terlaksana secara teratur dan terencana.

Penyusunan Anggaran Pendapatan dan Belanja Pengelola Masjid Baiturrohim dilakukan dalam rapat pengurus BPH yang dilaksanakan pada bulan November setiap tahunnya. Seluruh pengurus BPH dalam rapat tersebut mengusulkan kegiatan-kegiatan yang akan dilaksanakan pada tahun anggaran.

4. Pencatatan Keuangan Pengelola Masjid Baiturrohim

Laporan keuangan Pengelola Masjid AlMarkaz Makassar, sangat erat hubungannya dengan proses pencatatan transaksi yang dilakukan yang berhubungan dengan penerimaan dan pengeluaran kas.

Proses pencatatan dilakukan mulai diterimanya dana yang berasal dari kotak amal dan infaq. Proses pengeluaran kas yang berawal dari permintaan dana yang dibuktikan dengan nota atau proposal kegiatan yang diajukan kepada bendahara, yang selanjutnya bendahara akan membuat laporan keuangan setiap minggunya yang akan disampaikan kepada jamaah ketika hari jum`at.

Berikut ini dapat disajikan siklus pelaporan keuangan pengelola Masjid Baiturrohim Bojongmengger Cijeungjing.

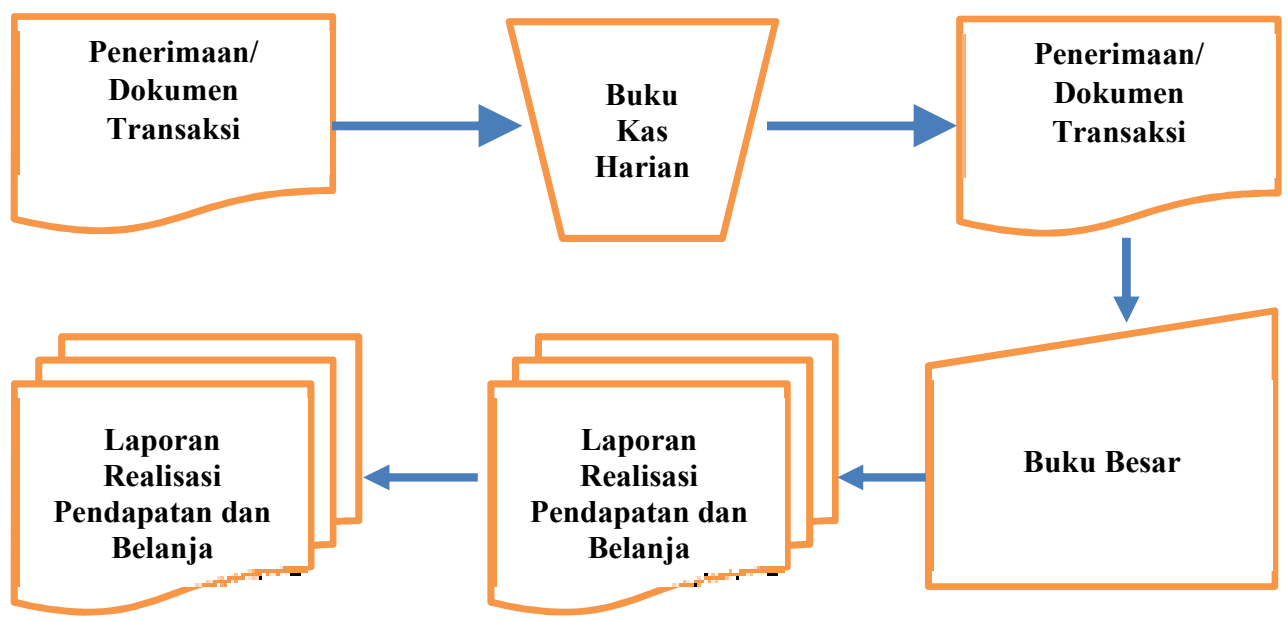

Gambar 1.

Siklus Pelaporan Keuangan Pengelola Masjid Baiturrohim Bojongmengger

Buku pencatatan yang digunakan oleh Pengelola Masjid Baiturrohim yaitu buku kas harian.

\section{Laporan Keuangan Pengelola Masjid Baiturrohim}

Bentuk akuntabilitas dari suatu organisasi adalah laporan keuangan. Laporan keuangan digunakan untuk melihat keadaan suatu organisasi. Laporan keuangan Pengelola Masjid Baiturrohim disusun oleh bendahara, dan bagian administrasi dan pembukuan, dan disampaikan kepada jamaah setiap jum 'at yang berisi laporan penerimaan dan pengeluaran selama satu minggu. Penyampaian laporan keuangan setiap jum at dilakukan sebagai media transparansi oleh pihak pengelola kepada jamaah yang telah memberikan sumberdaya. Laporan keuangan yang digunakan oleh Pengelola Masjid Baiturrohim mengikuti format yang disusun sendiri oleh pihak Pengelola Masjid Baiturrogim 
yakni bendahara dan bagian pembukuan Dari laporan keuangan yang telah dibuat setiap minggunya, dapat diketahui berapa jumlah uang yang masuk dan berapa jumlah uang yang keluar dalam setiap minggunya, hal ini bertujuan untuk mengontrol keuangan dari Pengelola Masjid Baiturrohim. Manajemen keuangan pada Pengelola Masjid Baiturrohim pada dasarnya berdasarkan akuntansi berbasis kas, karena pencatatan yang digunakan hanya mencatat pengeluaran dan penerimaan kas, dan pencatatan yang dilakukan berdasarkan waktu kas masuk dan kas keluar.

Laporan mingguan inilah dibacakan oleh pihak pengelola Masjid Baiturohim kepada jamaah sebelum acara jum 'at dimulai. Selain membuat laporan keuangan setiap minggu, bendahara dan bagian pembukuan Masjid Baiturohim juga membuat laporan bulanan, yang merupakan rekap dari setiap pengeluaran minggunya. Setelah membuat laporan bulanan, selanjutnya bendahara dan bagian pembukuan Masjid Baiturrohim membuat laporan realisasi pendapatan dan belanja dan laporan suplesi arus kas.

\section{Pembahasan}

Berdasarkan temuan dan hasil penelitian yang dilakukan secara keseluruhan DKM Baiturrohim telah melaksanakan pencatatan keuangan yang baik dalam melaksanakan fungsi penganggaran kegiatan masjid meskipun masih bersifat sederhana dan memerlukan rekomendasi peneliti untuk ditindaklanjuti oleh pengurus DKM Baiturrohim sehingga mampu menjalankan fungsi masjid sebagai organisasi nirlaba yang sukses dalam secara finansial organisasi dengan menjalankan manajemen keuangan yaitu: ramalan dan anggaran, sistem pelaporan keuangan yang tepat waktu, tata kelola yang baik, lini bisnis (misi) yang jelas, perencanaan arus kas, pengendalian fiskal dan goodwill yang banyak.

\section{Identifikasi Sumber Pendapatan}

Rekomendasi penyajian berdasarkan PSAK No. 45 untuk identifikasi sumber pendapatan adalah suatu format dalam bentuk catatan khusus yang berisi asal, sumber pendapatan, kelompok pendapatan, termasuk periode diperolehnya pendapatan.

Tabel 2.

Identifikasi Sumber Pendapatan

\begin{tabular}{|l|l|l|l|l|l|}
\hline \multirow{2}{*}{ No. Asal/ Sumber Pendapatan } & \multirow{2}{*}{ Kode } & \multicolumn{2}{|c|}{$\begin{array}{c}\text { Kelompok Pendapatan (isi } \\
\text { dengan tanda } \checkmark\end{array}$} & \multirow{2}{*}{$\begin{array}{c}\text { Periode } \\
\text { diperolehnya } \\
\text { Pendapatan }\end{array}$} \\
\cline { 4 - 5 } & & $\begin{array}{c}\text { Pendapatan } \\
\text { Terikat } \\
\text { Temporer }\end{array}$ & $\begin{array}{c}\text { Pendapatan } \\
\text { Tidak Terikat }\end{array}$ & \\
\hline & & & & & \\
\hline & & & & & \\
\hline & & & & & \\
\hline
\end{tabular}

Sumber: Diptyana, 2009:7

\section{Identifikasi Aktivitas}

Rekomendasi penyajian Identifikasi dan Klasifikasi Aktivitas yang dapat berdasarkan PSAK No. 45 dapat dilihat pada tabel berikut ini.

Tabel 3.

Identifikasi Aktivitas

\begin{tabular}{|c|c|c|c|}
\hline $\begin{array}{c}\text { Nama/ Deskripsi } \\
\text { Aktivitas }\end{array}$ & Kode & Tujuan & Periode Pelaksanaan \\
\hline (nama kegiatan) & & $\begin{array}{l}\text { isi dengan alasan atau tujuan } \\
\text { dilakukannya aktivitas ini. } \\
\text { Tujuan aktivitas harus sinkron } \\
\text { dengan tujuan organisasi }\end{array}$ & $\begin{array}{c}\text { (mingguan }(M), \\
\text { bulanan }(B), 2 \text { minggu } \\
\text { sekali }(2 M), \text { Tahunan } \\
(T), \text { tidak rutin }(T R)\end{array}$ \\
\hline
\end{tabular}

Sumber: Diptyana, 2009:8 


\section{Rekomendasi Penyusunan Anggaran Berbasis Aktivitas}

Periode penyusunan anggaran setiap organisasi dapat berbeda-beda. Asda yang tahunan ada yang setiap semester, tergantung dari kebutuhan organisasi. Pada umumnya anggaran ditentukan setiap tahun. Namun, evaluasinya dilakukan setiap bulan atau triwulan.

Rekomendasi yang dapat diberikan sekaitan dengan penyusunan anggaran berbasis aktivitas menurut PSAK No. 45 dapat menggunakan acuan-acuan berikut ini.

1. Jika ada saldo atau sisa dana yang berasal dari surplus periode sebelumnya, maka masukkan nilai sisa tersebut dalam "Saldo Awal".

2. Berikan kode Saldo Awal dengan SA.

3. Setelah menentukan berapa rupiah Pendapatan Terikat dan Pendapatan Tidak Tetap/ Terikat, masukkan kode dan data Pendapatan tersebut ke dalam Tabel.

4. Masukkan nama-mana kegiatan/ aktivitas sebagaimana pada Tabel 4 yang mengakibatkan biaya tersebut.

5. Selanjutnya, sebutkan jumlah Rupiahnya, serta tentukan pula kapan biaya tersebut harus dibayarkan.

Tabel 4.

Anggaran Pendapatan dan Biaya Berbasis Aktivitas

\section{ANGGARAN PENDAPATAN DAN BIAYA \\ [Nama Masjid] \\ [Alamat Masjid] \\ [Tahun]}

\begin{tabular}{|c|c|c|c|c|c|c|c|c|c|c|c|c|c|c|c|c|c|c|c|}
\hline \multirow{2}{*}{$\begin{array}{l}\text { No. } \\
\text { Urut }\end{array}$} & \multirow{2}{*}{\begin{tabular}{|l|} 
Kode \\
Akun
\end{tabular}} & \multirow{2}{*}{\begin{tabular}{|c|} 
Deskripsi \\
Akun
\end{tabular}} & \multirow{2}{*}{$\begin{array}{c}\text { Tujuan } \\
\text { Aktivitas }\end{array}$} & \multirow{2}{*}{ Unit } & \multirow{2}{*}{ Frekuensi } & \multirow{2}{*}{$\begin{array}{l}\text { Rp/ } \\
\text { Unit }\end{array}$} & \multirow{2}{*}{\begin{tabular}{|c|} 
Jumlah \\
(Rp)
\end{tabular}} & \multicolumn{12}{|c|}{ Jadwal Pelaksanan } \\
\hline & & & & & & & & Jan & Feb & Mar & Apr & Mei & Jun & Jul & Agt & Sep. & Okt & Nop & Des \\
\hline & & & & & & & & & & & & 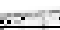 & & & & & & & \\
\hline & & & & & & $=$ & 87 & 7 & + & il & T & 11 & & & & & 1 & & \\
\hline & & & $m$ & -1 & 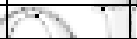 & $T$ & 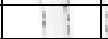 & $\Rightarrow$ & & 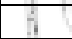 & 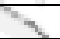 & +1 & & & & the & & & \\
\hline & $\because \approx$ & 7 & 1. & & & 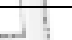 & & : & & 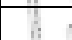 & $\because$ & 1 & & $x$ & & & & & \\
\hline & & & $7 \times$ & & 1 & - & & 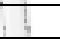 & 3 & H & 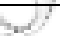 & 2 & & & & & & & \\
\hline & $\sin \theta$ & -2 & 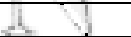 & a & & 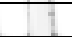 & & .2 & & 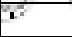 & & & & & & & & & \\
\hline & & & & & & & . & & & & & & & & & & & & \\
\hline & & & & & & & & & & & & & & & & & & & \\
\hline & & & & & & & & & & & & & & & & & & & \\
\hline
\end{tabular}

\section{KESIMPULAN \\ Simpulan}

Berdasarkan hasil penelitian terhadap pelaksanaan penganggaran pada Masjid Baiturrohim Desa Bojongmengger sebagai organisasi nirlaba yang diharapkan memenuhi kriteria/ standar pelaksanaan laporan keuangan terutama PSAK No. 45, dapat penulis simpulkan bahwa:

1. Pelaksanaan Penganggaran pada Masjid Baiturrohim sudah memenuhi unsur, identifikasi Pendapatan, Identifikasi Aktivitas dan Laporan Realisasi Anggaran yang masih seberhana sehingga belum terdokumentasikan dan mampu menginformasikan dengan baik sesuai dengan standar (PSAK No. 45).

2. Pengelolaan keuangan pada Masjid Baiturrohim Desa Bojongmengger dimulai dari penyusunan anggaran pendapatan dan belanja selama satu tahun, pencatatan penerimaan dan pengeluaran pada buku kas harian, pelaporan setiap bulanan serta pembuatan laporan realisasi pendapatan dan belanja untuk bulan yang berjalan masih sederhana.

3. Terkadang masih ada kegiatan yang belum teridentifikasi sejak awal namun perlu dilaksanakan sehingga menyebabkan kegiatan yang sudah terprogram mengalami penundaan atau tidak terlaksana meskipun dengan persentase yang sangat jarang.

\section{Saran}

Saran yang dapat disampaikan penulis diantaranya sebagai berikut:

1. Pengurus Masjid (DKM) Baiturrohim dalam melaksanakan kegiatan Penganggaran sebaiknya menggunakan acuan pada PSAK No. 45.

2. Pengurus Masjid (DKM) Baiturrohim sebaiknya menyusun Laporan Realisasi 
Anggaran dan memberikannya kepada Donatur Tetap sebagai bentuk akuntabilitas penggunaan dana.

3. Perlunya pembinaan lanjutan mengenai pengelolaan keuangan dalam aspek pencatatan dan pelaporan penerimaan serta penggunaan dana pada Masjid Baiturrohim agar kualitas laporan keuanagn dapat diukur.

\section{DAFTAR PUSTAKA}

Diptyana, Pepie. 2009. Modul Pelatihan Pencatatan Keuangan Dengan Identifikasi Aktivitas Untuk Penganggaran Masjid. Surabaya: STIE Perbanas.

Maleong, Lexy J. 2012. Metode penelitian kualitatif. Bandung, PT Remaja Rosdakarya.

Sochimin. 2015. Praktik Manajemen Keuangan Masjid Berbasis Pembedayaan Ekonomi Umat di Kota Purwokerto. IAIN Purwokerto.

Sugiyono, 2010. Metode Penelitian Kuantitatif. Bandung: Alfabeta. 